\title{
The Two DUF642 At5g11420 and At4g32460-Encoded Proteins Interact In Vitro with the AtPME3 Catalytic Domain
}

\author{
Esther Zúñiga-Sánchez and Alicia Gamboa-de Buen \\ Universidad Nacional Autónoma de México \\ México
}

\section{Introduction}

The plant cell wall provides structural integrity to plant tissues and regulates cellular growth and form. The cell wall is a dynamic compartment that varies in composition and structure during plant development and in response to different environmental signals. During cell division, the cell plate is rapidly generated. The biogenesis of this new cell wall requires the delivery of vesicles containing newly synthesised material. Cell surface material that includes plasma membrane proteins and cell wall components can be also rapidly delivered to the forming cell plate (Dhonukshe et al., 2006). The three different layers that can compose the cell wall are the middle lamella, primary cell wall and secondary cell wall. The middle lamella, which is a pectinaceous interface, is deposited soon after mitosis to create a boundary between the two daughter nuclei and is important for the adhesion of neighbouring cells. The primary cell wall is deposited throughout cell growth and expansion. These two processes require a continuous synthesis and exportation of cell wall components that have to be reorganised in the cell wall network. The secondary cell wall is deposited when cell growth has ceased and is not present in all cell types.

\subsection{Polysaccharide composition of the cell wall}

The primary cell wall is composed of diverse polysaccharides (85-95\%) and cell wall proteins with different functions (5-15\%, CWP). Cellulose, hemicelluloses (e.g., xyloglucans) and pectins (e.g., homogalacturonans) are the main types of polysaccharides present in cell wall. Cellulose microfibrils confer rigidity to the cell wall and interact with hemicelluloses to provide structure to the network. These polysaccharide interactions could restrict access of enzymes to their substrates; however, this network can be modified during plant development by different proteins that interact with the network components or by enzymes that modify the polysaccharides (Harpster et al., 2002). The polysaccharides are not the only contributor to cell wall integrity during plant development. Recently, it was demonstrated that the presence of cellulose is essential to maintain the polar distribution of proteins at the plasma membrane. The polar distribution of PIN transporters for the phytohormone auxin is disrupted by a pharmacological interference with cellulose or by 
mechanical interference with the cell wall (Feraru et al., 2011). Pectins, which are a major component of primary cell wall, are a large group of complex polysaccharides that are synthesised in the Golgi and transported to the cell wall by secretory vesicles (Sterling et al., 2001). Methylesterification of homogalacturonan (HG) occurs in the plant Golgi apparatus, possibly by a S-adenosylmethionine (SAM) methyltransferase named Cotton Golgi-Related3 (CGR3) (Held et al., 2011). HG is delivered to the cell wall in a highly methylesterified state, and the modulation of this state is a very important process in plant development. Highly esterified pectins are present in the proliferating zone of different tissues, whereas the cell walls of differentiating cells present abundant non-esterified pectins (Barany et al., 2010).

\subsection{Protein composition of the cell wall}

The cell wall composition is continuously modified by enzyme action during growth and development and in response to environmental conditions (Cassab, 1998). Proteins with enzyme activity and modulatory activity are present with different abundances in different cell types. Approximately 400 cell wall proteins that have been detected in cell wall proteomes have been classified into eight categories on the basis of predicted biochemical functions (Jamet et al., 2006). Members of seven of the eight groups have been previously defined as cell wall proteins involved in different aspects of cell wall dynamics. Many proteins have been detected in cell wall proteomes isolated from apoplastic fluids obtained from seedlings and rosette leaves (Charmont et al., 2005; Boudart et al., 2005), vegetative tissue that included etiolated hypocotyls and stem (Ishrad et al., 2008; Minic et al., 2007) and cell suspension cultures (Chivasa et al., 2002; Bayer et al., 2006, Bordereis et al., 2002). These proteins present a domain with an unknown function and are grouped together. The study of the function of the different families of this group of proteins will provide information about the dynamic processes of the cell wall.

\subsubsection{Proteins acting on polysaccharides}

Xyloglucan endotransglycosylase/hydrolase (XTH) is a family of glycosyl hydrolases that transglycosylate xyloglucan to allow expansive cell growth. These hydrolases are involved in cell growth, fruit ripening, and reserve mobilisation following germination in xyloglucanstoring seeds. In Arabidopsis, 33 genes have been identified that code for these hydrolases. Different temporal and spatial expression patterns for these XTH genes suggest that this family is involved in the change of cell wall properties related to every developmental stage. For example, XHT5 is expressed in hypocotyls, root tips, and anther filaments, whereas XHT24 is localised in vasculature tissue from the cotyledons, leaves, and petals. However, there is also an overlapping of the XTH gene expression pattern that suggests a combinatorial action of this enzyme group (Becnel et al., 2006).

Pectin modification is catalysed by a large family of pectin methylesterases (PMEs). In Arabidopsis, 66 genes have been suggested to potentially encode PMEs and are expressed differentially during organ and tissue development. A pro-domain is present in approximately $70 \%$ of the Arabidopsis PME family members (Micheli, 2001). It has been suggested that this domain has an inhibitory function during transportation to the cell wall by vesicles. The carboxylic fragment with the catalytic domain has been detected in cell wall 
proteomes, but the complete protein is required for secretion (Wolf et al., 2009). The interaction of PME with proteins that inhibit its activity, which are called pectin methyesterase inhibitors (PMEIs), contributes to the modulation of the degree of the methylesterified state of the pectin in the cell wall during different developmental processes (Pelloux et al., 2007). During pollen germination, the pollen tube wall presents highly methylesterified pectins in the tip region and weakly methylesterified pectins along the tube. It has been suggested that the activity of PMEs during pollen tube growth is highly regulated by PMEIs (Dardelle et al., 2010). Local relaxation of the transmitting tract cell wall also results from changes in the methylesterification of pectins that possibly facilitate the growth of the pollen tubes in the extracellular matrix of this female tissue (Lehner et al., 2010). An important role of pectin modifications in the regulation of cell wall mechanics in the apical meristem tissue has also been suggested (Peaucelle et al., 2011). The demethylesterification of pectin by PME activity results in random and contiguous patterns of free carboxylic residues. These contiguous patterns promote $\mathrm{Ca}^{++}$binding, which generates a rigid cell wall. PMEs might also be involved in maintaining apoplastic $\mathrm{Ca}^{++}$ homeostasis. PME activity has been suggested to maintain apoplastic $\mathrm{Ca}^{++}$homeostasis during heat shock. The resulting cell wall remodelling maintains the plasma membrane integrity to confer thermotolerance to the soybean (Wu et al., 2010). The random release of protons promotes pectin degradation by polygalacturonases, which are enzymes that also affect the pectin network. Polygalacturonases (PGs) promote pectin disassembly and might be responsible for various cell separation processes. PG activities are associated with seed germination, organ abscission, anther dehiscence, pollen grain maturation, fruit softening and decay, and pollen tube growth. In Arabidopsis, 69 genes encode PGs with different spatial and temporal patterns. For example, At1g80170 is specifically expressed in the anther and pollen (González-Carranza et al., 2007).

Expansins are cell wall proteins that modify the mechanical properties of the cells to enable turgor-driven cell enlargement. Expansin genes are highly conserved in higher plants, and there are four different expansin families in plants. Multiple expansin genes are often expressed in association with developmental events such as root hair initiation or fruit growth. They are also involved in processes such as fruit ripening and abscission, although cell wall modification occurs without expansion. Expansins may also be involved in embryo growth and endosperm weakening during germination (Sampedro and Cosgrave, 2005). The localised expression of expansins is associated with the meristems and growth zones of the root and stems (Reinhardt et al., 1998).

\subsubsection{Oxido-reductases}

Peroxidases are implicated in many physiological phenomena that include cross-linking of cell wall components, defence against pathogens, and cell elongation. These enzymes have a great variety of substrates and can regulate growth by controlling the availability of elongation-promoting $\mathrm{H}_{2} \mathrm{O}_{2}$ in the cell wall (Passardi et al., 2004). In Arabidopsis, 73 genes have been reported to code for putative peroxidases (Valério et al., 2004), and AtPrx33 and AtPrx34 function is specifically related to root elongation (Passardi et al., 2006).

Germins are oligomeric enzymes with oxalate oxidase activity that are associated with the extracellular matrix. In Arabidopsis, this family contains 12 members that are expressed in 
almost every organ and developmental stage. AtGer1 has been implicated in germination, whereas AtGer2 is involved in seed maturation (Membré et al., 2000).

\subsubsection{Proteases}

Proteases cleave peptide bonds and are classified into four catalytic classes: Cys proteases, Ser carboxypeptidases, metalloproteases and Asp proteases. The Arabidopsis genome encodes 826 proteases that are classified into 60 families with high functional diversity. Plant proteases are key regulators of different biochemical processes that are related to meiosis, gametophyte survival, embryogenesis, seed coat formation, cuticle deposition, epidermal cell fate, stomata development, chloroplast biogenesis, and local and systemic defence responses (van der Hoorn, 2008). Some proteases have been detected in cell wall proteomes, especially in cell suspension cultures.

\subsubsection{Proteins that have interacting domains with no enzymatic activity}

LRR proteins are frequently implicated in protein-protein interactions and are localised in the different subcellular compartments (Kajava, 1998). The LRR superfamily includes polygalacturonase-inhibiting proteins (PGIPs) that are present in the cell wall and are involved in disease resistance as well as growth and development (Di et al., 2006). FLOR 1, a putative PGIP protein, has been detected in cell wall proteomes but is also localised intracellularly, as more than $70 \%$ of the PGIP in Pisum sativum was reported to be distributed in the cytoplasm (Acevedo et al., 2004; Hoffman \& Turner, 1984).

Pectin methyl esterases inhibitors (PMEIs) are a diverse group of proteins that belong to the family of invertase inhibitors (INHs). PMEIs share with INHs a domain that is characterised by four conserved cysteine residues that can form two disulfide bonds (Juge, 2006). In Arabidopsis, there is an spatial patterning of cell wall PMEI at the pollen tip (Röckel et al., 2008).

Lectins are a diverse group of carbohydrate specific binding proteins that are involved in signal transduction (Lannoo et al., 2007). This group of proteins has interacting domains but does not show catalytic activity. The group presents with varying cellular localisation, which suggests a role in signal transduction between the different cellular compartments (Van Damme et al., 2004).

\subsubsection{Proteins involved in signalling}

In plants, there is a large subclass of receptor-like kinases that have extracellular LRRs in the receptor domain and are involved in signal transduction during development or defence (Clark et al., 1997). Arabinogalactan proteins (AGPs) are hydroxyproline-rich glycoproteins that are also involved in signalling. This family contributes to defensive, adhesive, nutrient and guidance function during pollen-pistil interactions (Cassab, 1998).

\subsubsection{Proteins related to lipid metabolism}

Lipases (LTPs) are hydrolytic enzymes with multifunctional properties. GDSL lipases are mainly involved in the regulation of plant development, morphogenesis, synthesis of secondary metabolites and defence responses (Ruppert et al., 2005). 


\subsubsection{Structural proteins}

LRR-extensins were the only group of structural proteins detected in cell wall proteomes. This family may be involved in the local regulation of cell wall expansion. Eleven genes have been described in Arabidopsis; four of them are pollen specific (Baumberger et al., 2003).

\subsubsection{Unknown proteins}

Approximately 5 to $30 \%$ of the total proteins from different cell wall proteomes have been classified as hypothetical, expressed, putative, unknown or with a domain of unknown function (DUF), especially in cell suspension culture. A domain is considered to be a discrete portion of a protein that folds independently of the rest of the protein and possesses its own function. Eight DUF protein families (DUF26, DUF231, DUF246, DUF248, DUF288, DUF642, DUF1005, DUF1680) are represented by one (or more) member(s) of the cell wall proteomes.

DUF26 is a plant-specific protein family composed of 40 members in Arabidopsis. Some members include DUF26 receptor-like kinases (RLKs), which are also known as cysteinerich RLK (CRKs). These proteins are involved in pathogen resistance and are transcriptionally induced by oxidative stress and pathogen attack (Wraczeck et al., 2010). At5g43980 encodes a protein present in the apoplastic fluid from rosette leaves that has been described as a plasmodesmal protein (PDLP1) involved in cell-to-cell communication processes (Thomas et al., 2008). The other DUF26 protein, which was detected in the cell wall proteome from cell suspension cultures, has not yet been assigned a function.

DUF231 is present in the proteins of the TRICHOME BIREFRINGENCE/TRICHOME BIREFRINGENCE-LIKE (TBR/TBL) plant family with 46 members in Arabidopsis. The role of this family in cellulose biosynthesis has been recently described; tbr mutants presented decreased levels of crystalline secondary wall cellulose in trichomes and stems (Bischoff et al., 2010a). Loss of TBR also results in increased PME activity and reduced pectin esterification, which suggests that TBL/DUF231 proteins are "bridging" proteins that crosslink different cell wall networks (Bischoff et al., 2010b). At5g06230 (TBL9) was found in a cell wall proteomic analysis of etiolated hypocotyls (Ishrad et al., 2008).

The domain unknown function 246 is considered to be a GDP-fucose o-fucosyltransferase domain in animals. This protein family has 16 members in Arabidopsis, and one of them, At1g51630, was detected in the proteome of cell suspension cultures.

DUF248 is a putative methyltransferase-related family of proteins with an ankyrin-like protein domain that is related to dehydration-responsive proteins. There are 29 proteins of this family in Arabidopsis, but only one, At5g14430, has been described in the cell wall proteome of cell suspension cultures (Bayer et al., 2006).

DUF288 is not a plant-specific family; this domain is also found in Caenorhabditis elegans proteins. In Arabidopsis, there are two members: At2g41770 and At3g57420. At3g57420 encode protein was purified from the apoplastic fluid of the cell wall proteome of rosette leaves (Boudart et al., 2005).

The DUF1005 domain has five integrants in Arabidopsis with two members that are similar to IMP dehydrogenase/GMP reductase from Medicago trunculata. The integrant isolated from 
the cell wall proteome of mature stems (At4g29310) does not have the other domain (Minic et al., 2007).

Two loci are described in Arabidopsis for the DUF1680 family, and one of them was purified from the cell wall proteome of mature stems.

The most important family of unknown proteins detected in cell wall proteomes is DUF642, which is a highly conserved plant-specific family that is present in angiosperms and gymnosperms (Albert et al., 2005, Vázquez-Lobo, personal communication). Arabidopsis has ten members. The At3g08030-encoded protein is present in all cell wall proteomes and is the only unknown protein that was also detected in a seed proteome from the Arabidopsis accession Cape Verde Island (Cvi) that has deeper seed dormancy (Chibani et al., 2006). At2g41800 and At1g80240-encoded proteins were only found in cell suspension cultures (Bayer et al., 2006), whereas At5g25460-encoded protein was found in vegetative and cell wall suspension cultures. At4g32460 and At5g11420-encoded proteins were both detected in apoplastic and vegetative tissues. The consistent presence of 6 members of this family in all cell wall proteomes suggest that the biochemical function of the DUF642 family is related to the regulation of the activity of cell-wall-modifying enzymes at different stages of plant development.

\subsection{DUF642 family}

The DUF642 protein family is highly conserved, is widespread in plants, and might be involved in important basic developmental processes. Members of this family have been observed in basal angiosperms such as Amborella, in both monocots and dicots and also in gymnosperm species. The relevance of the DUF642 family to plant evolution was discussed by Albert and collaborators (2005). The proteins encoded by the DUF642 gene family have a unique, highly conserved domain with no assigned function that shares similarity with the galactose-binding domain. The ten members of this family identified in Arabidopsis contain a signal peptide of 20 to 30 amino acids in the $\mathrm{N}$-terminus region that could promote their localisation in the endomembrane system or in the cell wall. Three of the ten Arabidopsis genes (At1g29980, At2g34510 and At5g14150) encode proteins have been described as glycosil-phosphatidyl-inositol anchored proteins (Figure 1) (Borner et al., 2003, Dunkley et al., 2006). The At2g41800-encoded protein has been detected in the Arabidopsis cell wall proteome. The proteins encoded by At5g11420 and At2g34510 contain a ATP/GTP binding site motif that has been described in many proteins involved in signal transduction processes.

Although a function has not yet been assigned for this family, it has been suggested that some members could be involved in different developmental processes. Organ-specific expression has been described for the flowers of two DUF642 members, At3g08030 and At5g11420 (Wellmer et al., 2004), and for the stems for a DUF642 Medicago sativa gene (Abrahams et al., 1995). At4g32460, At5g14150 and At2g41800 have been described as papillar cell-specific genes in flowers (Tung et al., 2005). Changes in DUF642 gene expression have been also detected under specific environmental conditions. Saline stress promotes the expression of $A t 2 g 41810$ (Kreps et al., 2002), and an RNA increase in the three DUF642 Arabidopsis homologs (At3g08030, At5g25460 and At4g32460) was described during the priming and germination of Brassica oleracea seeds (Soeda et al., 2005). 


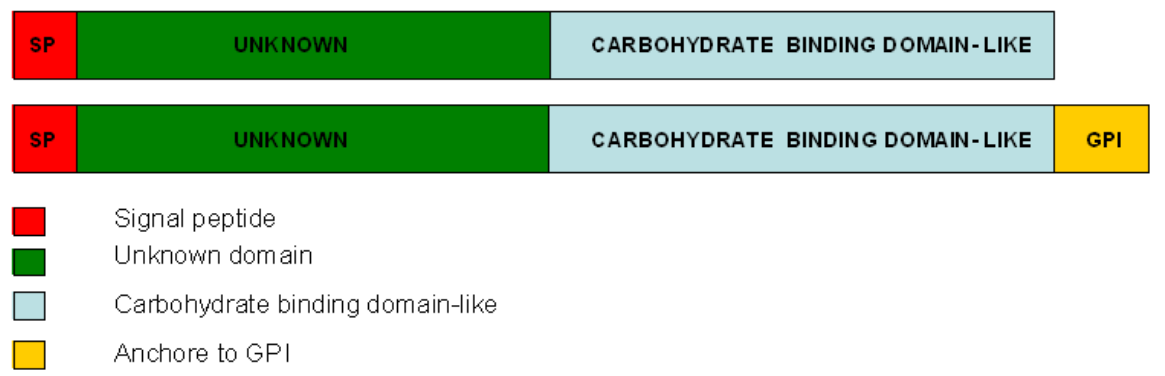

Fig. 1. DUF642 proteins have a basic structure divided into two subdomains and a signal peptide. N-terminus subdomain has not function or putative function assigned while C-terminus subdomain has homology with a carbohydrate binding domain. Some DUF642 proteins present in their C-terminus a GPI anchored motive.

We characterised the plant-specific DUF642 protein family using different approaches. We determined mRNA expression in different plant tissues, characterised sequence features and detected the potential interaction of proteins with two members of this family in Arabidopsis (At5g11420 and At4g32460-encoded proteins). The proteins identified by LC/MS/MS analysis were the leucine-rich repeat protein FLOR1 (FLR1), a vegetative storage protein (VSP1), and a ubiquitous pectin methylesterase isoform (PME3) isolated from Arabidopsis flowers and leaves. Based on the structural characteristics of the DUF642 family of proteins and the associated affinity chromatography analyses, we propose that these proteins could interact specifically with other cellular components via their DUF642 domain and are therefore potentially involved in developmental plant processes. Our results provide a starting point for defining the function of the DUF642 family in plant development.

\section{Materials and methods}

\subsection{Plant material and sample collection}

Arabidopsis thaliana from the Columbia (Col) ecotype plants were grown on MS plates (1X Murashige and Skoog basal salt mixture, $0.05 \%$ MES, $1 \%$ sucrose as carbon source and $0.8 \%$ agar) in a REVCO growth chamber under a long photoperiod (16-h light 8-h darkness) at $20^{\circ} \mathrm{C}$. Fifteen-day-old seedlings were transferred to pots containing Metro-Mix 200 (Scotts Company) soil and grown under the same controlled conditions.

\subsection{Reverse transcriptase-polymerase chain reaction (RT-PCR)}

Arabidopsis samples from different tissues were collected from 15-day-old seedlings and flowering plants, immediately frozen in liquid nitrogen and stored at $-80^{\circ} \mathrm{C}$ until analysis. Total RNA from different tissues was isolated using TRIZOL according to the supplier's instructions (INVITROGEN ${ }^{\mathrm{TM}}$ ). cDNA templates for the amplification by PCR were prepared using SuperScript II reverse transcriptase (INVITROGEN'M) according to the manufacturer's 
instructions. Based on the sequence of each gene member of the DUF642 family of Arabidopsis, the following primers were synthesised:

At2g41800: F 5'tcctcctcctatctctctgc 3' and R 5'aaacggttctcttcctgc 3';

At2g41810: F 5'atgggccaaaaaaacac $3^{\prime}$ and R $5^{\prime}$ atgtctctcgttctctctc $3^{\prime}$;

At3g08030: F 5'ggttcccaaagccattattc $3^{\prime}$ and R 5'acaatctcgtcaatgacagg $3^{\prime}$;

At5g25460: F 5'cttccttcttttcatcgec 3' and R 5'acgagaaatcatcgctcc 3';

At5g11420: F 5'ccatgggcttcagtgacgggatg $3^{\prime}$ and R 5'agatctgagtgtctttcccgc $3^{\prime}$;

At4g32460: F 5'gtgatagtgcttcttctccttcac $3^{\prime}$ and R $5^{\prime}$ agcgacgaatctcaatgac $3^{\prime}$;

At1g80240: F 5'aaaagcagcactcctcttag $3^{\prime}$ and R 5' atcattggtccetcacaac $3^{\prime}$;

At1g29980: F 5'ccgagcaacaatagatgc 3' and R 5'actgtagaacgcaactctgg 3';

At2g34510: F 5'ttggtctctccattgtggc $3^{\prime}$ and R 5'ccttaacgtcatcaatcacagg 3';

At5g14150: F 5'ttgcgectcttcagattttt3' and R 5'cttctcaccagagccagtcc $3^{\prime}$.

Polymerase chain reaction (PCR) was performed under the following conditions: $94^{\circ} \mathrm{C} 5$ min; 35 cycles of $94^{\circ} \mathrm{C} 30 \mathrm{sec}, 60-62^{\circ} \mathrm{C} 30 \mathrm{sec}, 72^{\circ} \mathrm{C} 1 \mathrm{~min} 30 \mathrm{sec}, 72^{\circ} \mathrm{C} 5 \mathrm{~min}$.

\subsection{Sequence analysis and database search}

The 10 DUF642 protein sequences of Arabidopsis were obtained from GenBank (NP_973938: At1g29980; NP_178141: At1g80240; AAC02768: At2g41800; AAC02767, NP_181712: At2g41810; AAC26689: At2g34510; AAO00904: At3g08030; ABF19001: At4g32460; NP_196919: At5g14150; AAN31807: At5g11420 and AAP37805: At5g25460). A multiple sequence alignment, using only the DUF642 protein domain, was performed using ClustalW from the Bio Edit Sequence Alignment Editor. The possible secondary structure of the proteins coded for by At5g11420 and At4g32460 was compared on-line using the Draw an HCA (Hydrophobic Cluster Analysis) program (http://ca.expasy.org/tools/) as described in Gaboriaud et al. (1987).

\subsection{Recombinant 5xHis-tagged DUF642 proteins and the resin-bound DUF642 protein affinity column}

The entire open reading frame of the DUF642 genes At5g11420 and At4g32460, without the signal-peptide-coding region, was amplified using PCR. The primers used for the At5g11420 were MET11420 (5'ccatgggcttcagtgacgggatg3'), which includes an in-frame ATG, and primer 11420FIN2 (5'agatctagtgtcttttcccgca3'). For the amplification of the carboxyl-terminus truncated protein, the At5g11420 ( $\Delta 11420)$ forward primer MET11420 and the reverse primer 11420FIN3 (5'agatctcggcttacgagcactgag3') were used. At4g32460 was amplified using the following primers: MET32460 (5'ccatgggcttcaatgatggactactacc3') and 32460FIN2 (5'agatctgcgtaaaacgtactgtaga3'). The amplified regions of these genes were cloned into the pQE60 vector using the NcoI and BglII restriction sites. A negative control was performed using the empty pQE60 vector. Protein expression and purification were performed following the supplier's instructions, and the recombinant proteins with the histidine tail were detected using western blot analysis with a Ni-NTA conjugate (QIAGEN). The three recombinant proteins were eluted as a single band and were identified to have the histidine tail. No protein was detected when the empty vector was used. The elution process was the only step omitted when the column was prepared for each recombinant protein. 


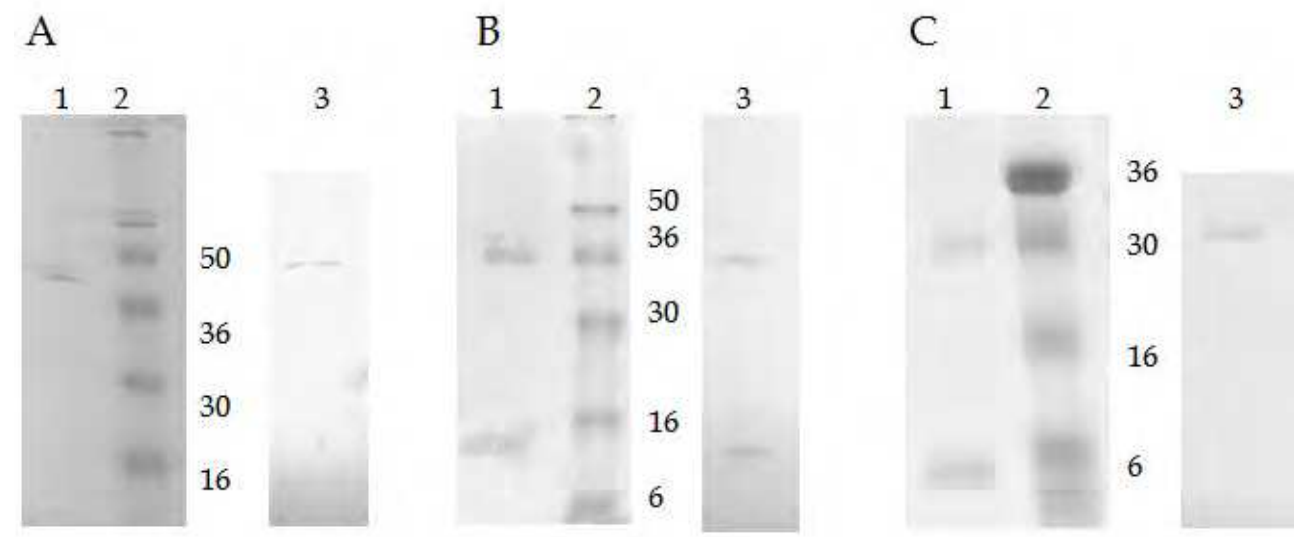

Fig. 2. Recombinant 5xHis-tagged DUF642 proteins.

A) Purification of the 32460 recombinant protein. 12\% PAGE Gels were stained with Coomassie Blue. The column was eluted with $250 \mathrm{mM}$ Imidazole (Lane 1). Western Blot of the eluted fraction (NiNta beads with phosphatase alkaline secondary antibody). The band of approximately $40 \mathrm{kDa}$ corresponds to the calculated molecular weight for this protein (Lane 3). B) Purification of the 11420 recombinant protein. 12\% PAGE Gels were stained with Coomassie Blue. The column was eluted with $250 \mathrm{mM}$ Imidazole (Lane 1). Western Blot of the eluted fraction (NiNta beads with phosphatase alkaline second antibody). The band of approximately $40 \mathrm{kDa}$ corresponds to the calculated molecular weight for this protein (Lane 3). C) Purification of the $\Delta 11420$ recombinant protein. $12 \%$ PAGE Gels were stained with Coomassie Blue. The column was eluted with $250 \mathrm{mM}$ Imidazole (Lane 1). Western Blot of the eluted fraction (NiNta beads with phosphatase alkaline second antibody). The band of approximately $32 \mathrm{kDa}$ corresponds to the calculated molecular weight for this protein (Lane 3).

\subsection{Affinity chromatography of flower or leaf protein extracts}

Frozen flowers or leaves from Arabidopsis plants (10-20 g) were ground with a mortar and pestle and placed in two $40 \mathrm{ml}$ tubes with $14 \mathrm{ml}$ of extraction buffer $(50 \mathrm{mM}$ Tris- $\mathrm{HCl} \mathrm{pH}$ $7.5,3 \mathrm{mM} \mathrm{MgCl} 2,1 \mathrm{mM}$ PMSF). The crude homogenate was centrifuged at 15,000 xg for 30 min, and in the case of DUF642 affinity columns, the supernatant was loaded onto a previously equilibrated DEAE-Sephacel column $(2 \times 10 \mathrm{~cm})$ with extraction buffer at $4^{\circ} \mathrm{C}$. The resulting fraction was then used for affinity chromatography. The affinity column was prepared beforehand as described above and equilibrated with extraction buffer. The protein extracts from the different tissues were mixed for $1 \mathrm{~h}$ with the prepared resin at $25^{\circ} \mathrm{C}$ using gentle agitation in a ratio of $10 \mathrm{ml}$ of extract/ $0.2 \mathrm{ml}$ of agarose. The column was washed with $50 \mathrm{mM}$ Tris- $\mathrm{HCl} \mathrm{pH} 7.5,5 \mathrm{mM} \mathrm{MgCl} 2$ (50 vol) buffer to remove unbound proteins. Bound proteins were eluted with the same buffer containing different $\mathrm{NaCl}$ concentrations (100 to $1000 \mathrm{mM}$ ). These fractions were precipitated with cold acetone. Agarose and the empty vector column were used as negatives controls, and no bound proteins were detected (Gamboa et al., 2001). 
The fractions obtained in the affinity chromatography assays were analysed on denaturing $12 \%$ SDS-PAGE gels and stained with silver. Bands of interest were extracted from the gels and sent to the Proteomics Platform of the Eastern Genomics Center, Quebec, Canada, where the in-gel digest and mass spectrometry experiments were performed. Tryptic digestion was performed according to Shevchenko et al. (1996) and Havlis et al. (2003). Peptide samples were separated by online reversed-phase (RP) nanoscale capillary liquid chromatography (nano/LC) and analysed by electrospray mass spectrometry (ES/MS/MS).

Database searching. All MS/MS samples were analysed using Mascot (Matrix Science, London, UK; version 2.2.0)

Criteria for protein identification. Scaffold (version Scaffold-01_07_00, proteome Software Inc. Pórtland Oregon, OR) was used to validate MS/MS-based peptide and protein identifications. Peptide identifications were accepted if they could be established at greater than $95.0 \%$ probability as specified by the Peptide Prophet algorithm (Keller et al., 2002). Protein identifications were accepted if they could be established at greater than $95.0 \%$ probability and contained at least 2 identified peptides. Protein probabilities were assigned by the Protein Prophet algorithm.

Only one protein was identified for the protein bands derived from the two chromatography steps, DEAE-Sephacel and affinity chromatography (11420 and 32460 column affinity protocols).

\section{Results and discussion}

\subsection{Gene structure of the DUF642 family in Arabidopsis thaliana}

The DUF642 domain was only present in the ten Arabidopsis members described before, and all members had the same gene structure, which consisted of three exons and two introns (Figure 3). The first intron encoded the signal peptide, and an alternative usage of the first exon was detected for At1g29980 and At3g08030. The first intron was also included in the mRNA sequence for the At3g08030 gene. The expression of two different mRNAs has been found in different tissues, which suggests a possibly different protein subcellular localisation.

\subsection{DUF642 members are widely expressed in all Arabidopsis thaliana plant tissues}

The RT-PCR expression analysis of the ten DUF642 genes in different tissues including seedlings, stems, cauline leaves, rosette leaves, flowers, inflorescences and roots is shown in Figure 4. The genes with broad expression patterns are At1g80240, At5g11420, At5g25460 and At2g41800, whereas At1g29980 and At4g32460 were not detected in cauline leaves. At $2 g 41810$ expression was restricted to inflorescence tissue. The At $2 g 41810$-encoded protein exhibits $81 \%$ identity and $89 \%$ similarity to the At $2 g 41800$-encoded protein. In the inflorescence tissue, the At $2 \mathrm{~g} 41800$ transcript contained an additional region of $100 \mathrm{bp}$ corresponding to the first intron, which suggests an alternative use of the first exon described for At3g08030 and At1g29980. The gene with the most divergent sequence in the family, At5g14150, was also detected in the stem, flower, inflorescence, and root tissues and was detected at low levels in cauline leaves. 


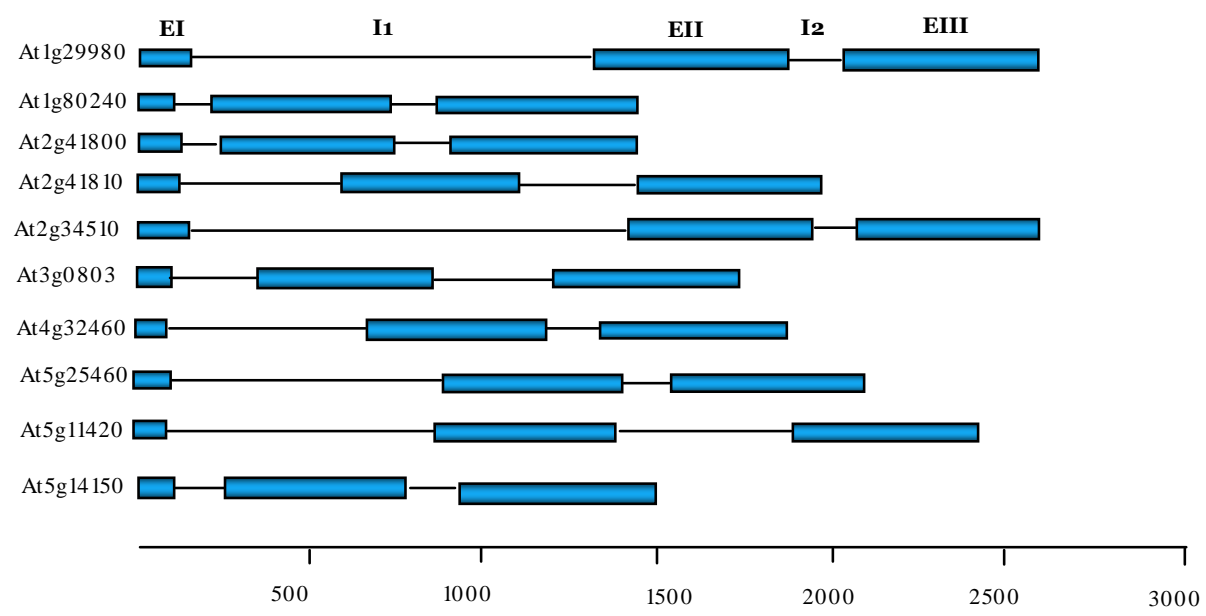

Fig. 3. Gene structure of DUF642 family in Arabidopsis thaliana.

EI: Exon 1, I1: Intron 1, EII: Exon 2, I2: Intron 2, EIII: Exon3

Our results are consistent with the microarray data described in the Gene Investigator Atlas (http://www.genevestigator.ethz.ch/), except for the At2g41810 gene. We did not find At2g41810 expression in the roots, but the Atlas indicated high expression. However, Kreps and collaborators (2002) demonstrated that the expression of this gene in the roots is induced by $\mathrm{NaCl}$ stress. These discrepancies in the results obtained in different studies could therefore be related to the different growth conditions used. Spatio-temporal expression analyses of this family will provide important information about its function. Cell-type-specific expression in the roots of the auxin-inducible DUF642 genes At2g41800 and At4g32460 was recently reported (Goda et al., 2004; Salazar-Iribe \& Gamboa-deBuen, unpublished data).

Transcriptomic analyses suggest that the expression of this family of genes is also affected by different environmental conditions. The expression of genes that encode DUF642 proteins could be inhibited or stimulated by different pathogens. Indeed, invasion by necrotrophic pathogens or insect attack has been shown to significantly reduce the expression of At5g11420, At5g25460, At4g32460 and At1g29980 in plant tissues (Hu et al., 2008; Ehlting et al., 2008). Conversely, an increase of DUF642 gene expression in response to biotrophic organisms has been reported in Arabidopsis transcriptomic analyses of sink-heterologous structures, such as galls. Furthermore, the $A t 3 g 08030$ and $A t 1 g 29980$ genes have been found to be up-regulated in response to Agrobacterium tumefaciens and Rhodococcus fascians invasion (Depuydt et al., 2009, Lee et al., 2009). At1g29980 has also been shown to be highly expressed in the giant cells induced by the root-knot nematode, Meloidogyne incognita (Barcalá et al., 2010), and the development of such sink structures is related to an increase in auxin (Grunewald et al., 2009). The study of the effect of nematode invasion on the gene expression of the DUF642 family will provide important functional insights. 

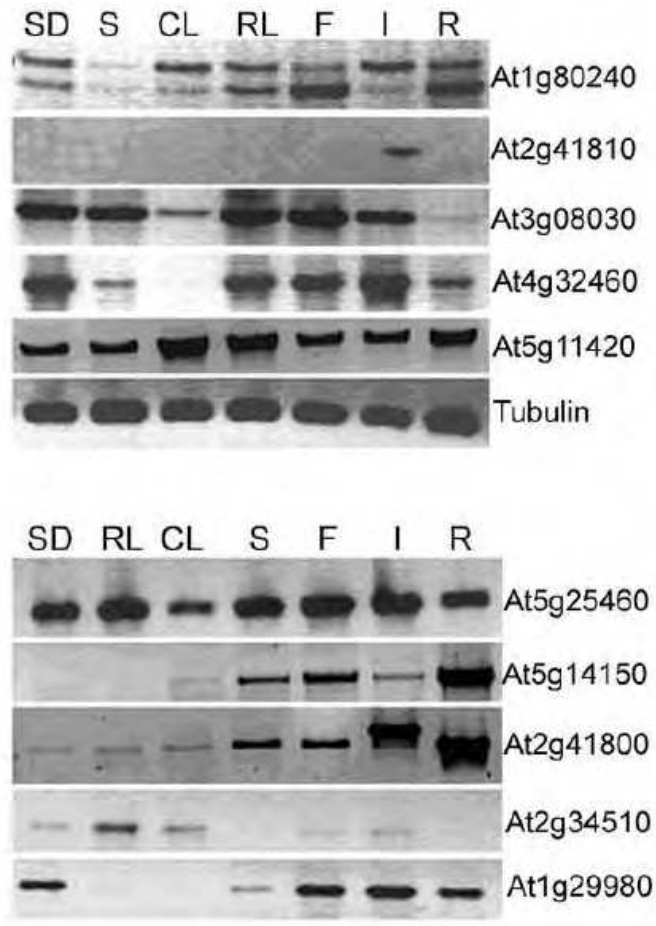

Fig. 4. RT-PCR expression of Arabidopsis thaliana DUF642 genes in various tissues. Seedlings (SD), rosette leaves (RL), cauline leaves (CL), stems (S), flowers (F), inflorescences (I), and roots $(\mathrm{R})$. The expression of tubulin was analyzed simultaneously as an internal standard.

\subsection{Comparison of the primary sequence of the ten Arabidopsis thaliana DUF642 family members}

The DUF642 gene family encodes proteins with an estimated molecular mass ranging from 39 to $44 \mathrm{kDa}$. These proteins contain the DUF642 amino acid domain, preceded by a 20-30 amino acid signaling peptide on the amino terminus. This signaling peptide could be involved in the cell wall localisation of DUF642 proteins in several plant organs. Alignment analysis of the ten Arabidopsis members shows an extensive conservation of the DUF642 domain; the percentage of identical and similar amino acids varies from $30 \%$ to $85 \%$ and $43 \%$ to $92 \%$, respectively (Figure $5 \mathrm{~A}$ ). About $30 \%$ of the amino acids distributed throughout the sequence of the DUF642 domain are hydrophobic. These residues are not identical, but they are similar among the different proteins. The comparison of the hypothetical secondary structure of $A t 5 g 11420$ and At4g32460-encoded proteins shows that the hydrophobic clusters present are similar (Figure 5B). Four conserved cysteine residues are present in all of the sequences as previously described for the pectin methyl esterase inhibitors localised in the cell wall (Juge, 2006). Because no catalytic activity has yet been assigned to the DUF642 domain, this family could be involved in specific carbohydrate or protein interactions. 
A

aT2 641: 1

AT2 641800

ATS 611420

aT3 608030

AT1629980

aTs 625460

BTS614150

AT2 63451

AT1680240

AT2641810
AT2 641800
ATS611420
AT4632460
AT3608030
AT1629980
AT5 625460
AT5614150
AT2634510
AT1680240

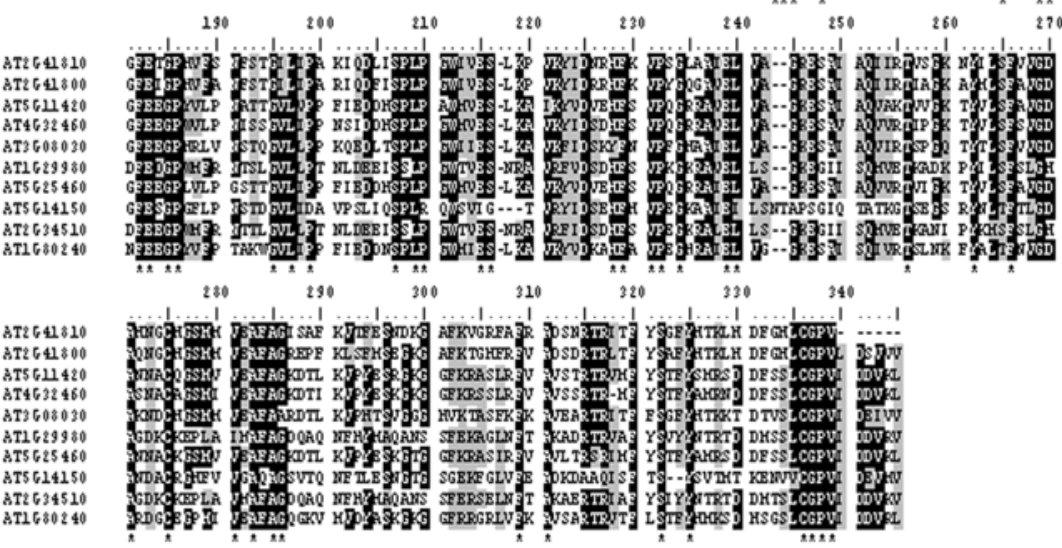

B
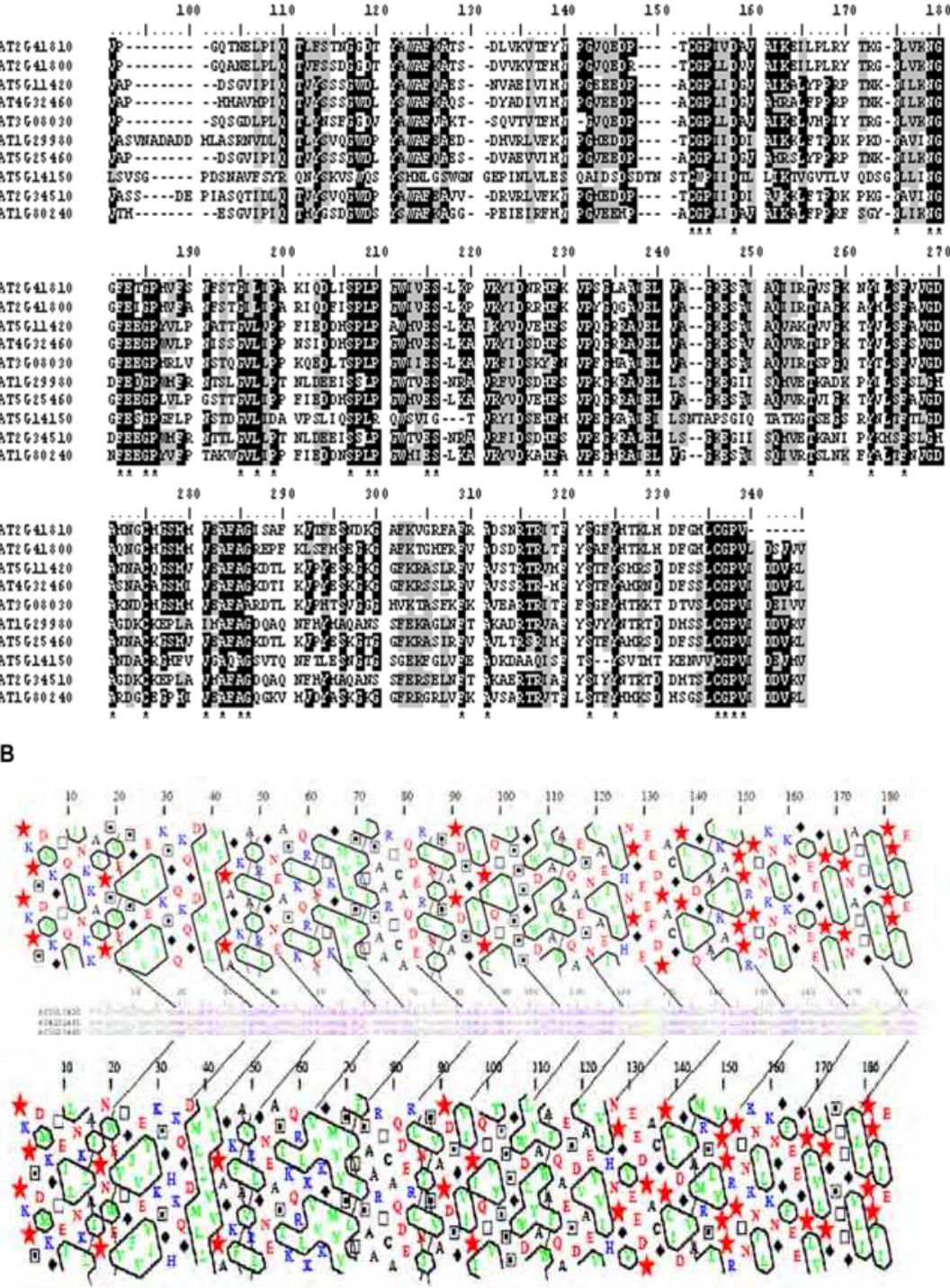

Fig. 5. DUF642 amino acid sequence and features.

(A) Clustal W alignment (BioEdit) of the DUF642 domain of the 10 Arabidopsis proteins is 
shown. The N-terminal region (comprising the signal peptide) was eliminated for the alignment. Shading indicates conserved amino acid and dark shading indicates identities. (B). Secondary structure comparison of 11420, top, and 32460, bottom. The initial 180 amino acid sequences of the DUF642 domain of both proteins are compared using "Draw an HCA" online program (http:/ / ca.expasy.org/tools/) (Gaboriaud et al., 1987). Amino acids forming putative hydrophobic clusters are grouped together. Compare similar patterns in both sequences. Star: P; dotted square: $S$; rhomb: $G$, and empty square: $Y$ residues; other amino acids in standard abbreviation.

Most of the members of the DUF642 family have a broad expression pattern in different plant tissues. A putative redundancy of function in this family should be considered because of the high conservation of the DUF642 domain; however, it is important to describe the organ, cell type and specific stress-related expression patterns for each gene to determine the individual gene function (Wellmer et al., 2004).

\subsection{DUF642 proteins have specific interactors in the flowers and leaves of Arabidopsis thaliana}

Recombinant 32460 protein interacts in vitro with the LRR protein FLR1 (Q9LH52, At3g12145), with VSP1 (Q93VJ6, At5g24780) and with PME (Q9LUL7, At3g14310) in flowers, whereas in leaves, it interacts with the same PME (At3g14310) (Figure 6). The recombinant 32460 protein interacts in vitro with three proteins with sizes of $38 \mathrm{kDa}, 37 \mathrm{kDa}$ and $29 \mathrm{kDa}$ from the flowers (Figure 6A). These proteins were identified as FLR1, PME, and VSP1, respectively (Figures 8A, B and C). It is important to note that FLR1 was not eluted by 500 $\mathrm{mM} \mathrm{NaCl}$, and VSP1 is only present in this fraction as determined in the interaction assay using the At5g11420-encoded protein. A $37 \mathrm{kDa}$ band was purified in the three salt fractions from leaf extracts and was identified as the same PME isoform described for the flowers. A $29 \mathrm{kDa}$ band was also eluted, and this protein was identified as a possible auxin-binding protein (Figure 6B). For all protein bands analysed, only a significant hit was assigned, as described in the material and methods.

The recombinant DUF642 11420-protein interacts in vitro with FLOR1 and VSP1 in flowers, but in leaves, it only interacts with PME (Figure 7). A high-purity protein fraction with two bands was obtained from the 11420-affinity column after the floral crude protein extracts were purified over several steps (Figure 7B). Different ionic strengths were used during elution; one $38 \mathrm{kDa}$ band was eluted at 100 and $200 \mathrm{mM} \mathrm{NaCl}$, whereas a $29 \mathrm{kDa}$ band was obtained at 200 and $500 \mathrm{mM} \mathrm{NaCl}$ (see arrows in Figure 7B). The $38 \mathrm{kDa}$ protein was identified as FLR1 (12\% coverage) and the $29 \mathrm{kDa}$ band as VSP1 (11\% coverage), as described in the methods (Figures $8 \mathrm{~A}$ and B). A $\Delta 11420$ protein without the carboxylic terminus that included the most divergent amino acid sequence was also used as a ligand. FLR1 was the only purified protein, which suggests that the carboxylic region is important for interaction with VSP1 (Figure 7C). At5g11420 is expressed in all Arabidopsis tissues, and therefore, we were interested in the determination of the proteins in the leaves that interact with the At5g11420-encoded protein. The same procedure, using the affinity column with a leaf extract protein fraction, was used. In the first two fractions, two bands of $45 \mathrm{kDa}$ and 32 $\mathrm{kDa}$ were detected. In the $500 \mathrm{mM} \mathrm{NaCl}$ fraction, three major bands of the following sizes were detected: $45 \mathrm{kDa}, 32 \mathrm{kDa}$ and $14 \mathrm{kDa}$ (Figure 7D). The identified 32 and $14 \mathrm{kDa}$ bands 
correspond to a PME (40\% coverage, Q9LUL7, At3g14310). The PME $14 \mathrm{kDa}$ band was also identified when the $\Delta 11420$ protein was used as the ligand (Figure $7 \mathrm{E}$ ). The two lowermolecular-weight bands contained the carboxyl region that includes the catalytic domain of the PME, and therefore, it is possible that the differences in their electrophoretic mobility are the result of post-translational modifications.
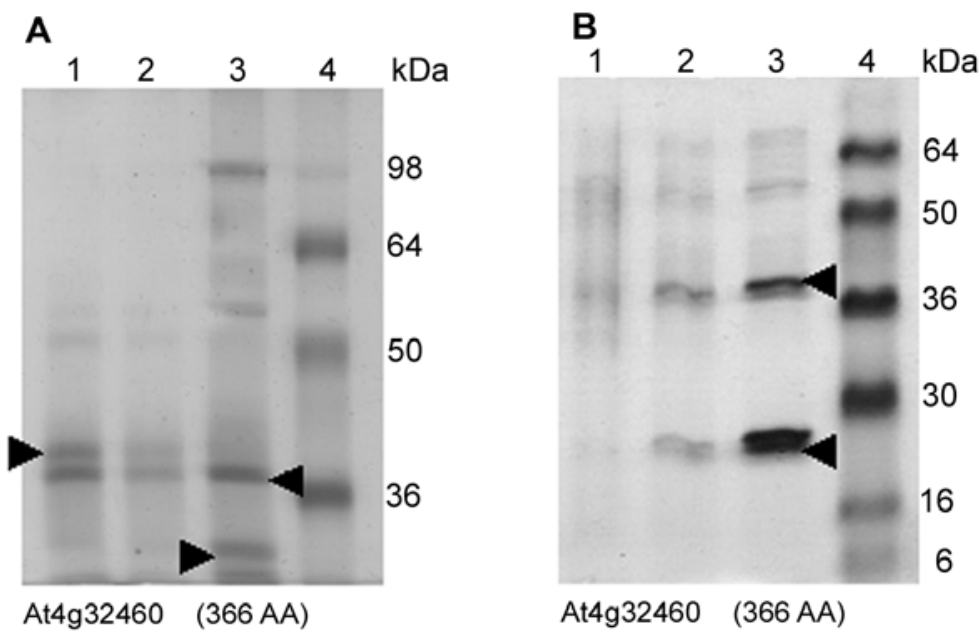

Fig. 6. 32460-protein in vitro interactors.

(A) Recombinant 32460 amino acid sequence. (B C) affinity chromatography assays of 32460 interactors from DEAE-Sephacel flow-through protein fraction from Arabidopsis thaliana flowers (B) and leaves(C). Silver staining of 12\% SDS-PAGE gel showing: (1) NaCl $100 \mathrm{mM}$, (2) $\mathrm{NaCl} 200 \mathrm{mM}$, (3) $\mathrm{NaCl} 500 \mathrm{mM}$ elution fractions, and (4) molecular weight reference. (B) Flower interactors of the 32460 recombinant protein. In (1) and (2) two main protein bands are seen; with molecular masses of 38 and 37, corresponding to FLR1 (arrow in (1)) and PME (upper arrow in (3)) respectively. In (3) the two bands with molecular masses of 37 and 29 were identified as PME and VSP1 respectively (see arrows in (3)).

(C) Leaf interactors of the 32460 protein. Fraction (3) was highly enriched with two bands with molecular masses of approximately 37 and 29. The $37 \mathrm{kDa}$ band was identified as the catalytic domain of a PME, while the $29 \mathrm{kDa}$ band was identified as a possible auxin-binding protein.

The proteins that interacted in vitro with the DUF642 11420 and 32460 proteins, i.e., FLOR1 and AtPME3, were detected in the cell wall proteomes (Figures 7A, B and C). Similar expression patterns reflect a possible in vivo interaction. FLOR1 is an LRR protein related to polygalacturonase inhibitors (PGIPs) that are highly expressed in vascular and meristem tissues. An intracellular localisation of FLOR1 has been also reported (Acevedo et al., 2004). AtPME3 (At3g14310) is expressed in the vascular tissue of seedlings, leaves, stems and roots and is involved in adventitious root formation (Guénin et al., 2011). Recently, we demonstrated that At4g32460 is also expressed in the meristems and in vascular tissue (Zúñiga-Sánchez \& Gamboa-deBuen, unpublished data). 
A

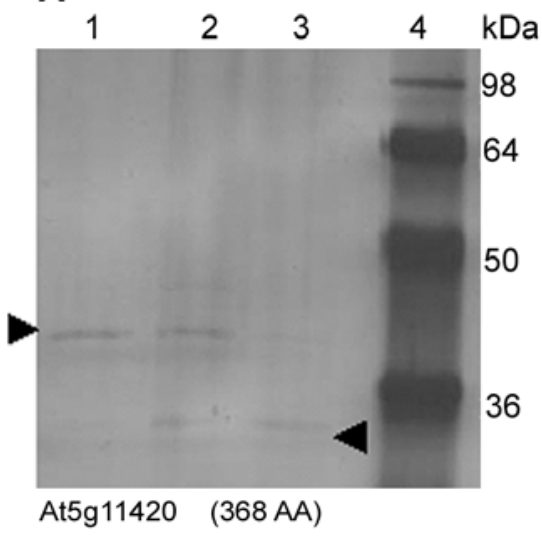

C

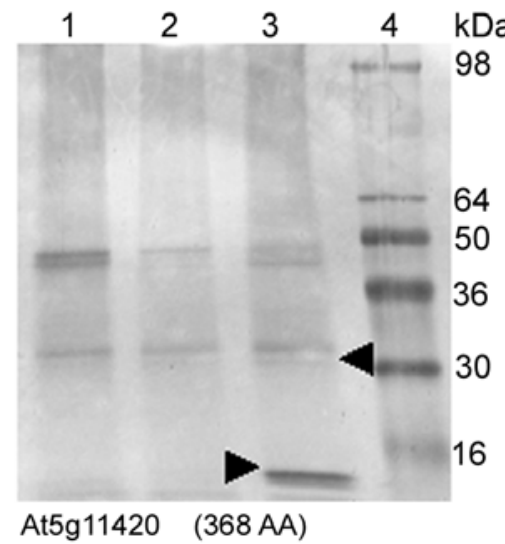

B

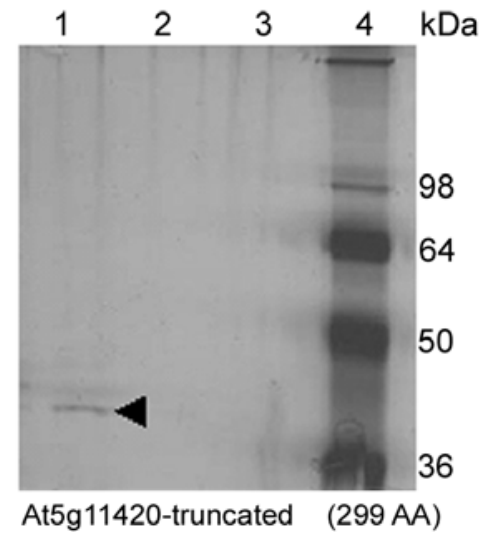

D

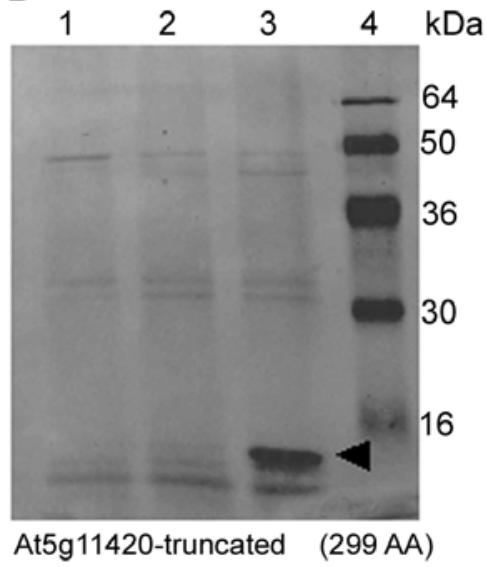

Fig. 7. 11420-protein in vitro interactors.

(ABCD) Affinity chromatography assays of 11420 interactors from DEAE-Sephacel flowthrough protein fraction of Arabidopsis thaliana flowers (B,C) and leaves (D,E); Silver staining of 12\% SDS-PAGE gels showing: (1) NaCl 100 mM, (2) NaCl 200 mM, (3) NaCl 500 mM elution fractions, and (4) molecular mass references.

(A) Flower interactors of the 11420 recombinant protein: Two protein bands are seen with molecular masses of 38 and 29 corresponding to FLR1 and VSP1 respectively (see arrows).

(B) Flower interactors of the 11420 -truncated protein $(\Delta 11420)$ : In $(1)$ only a $38 \mathrm{kDa}$ protein is detected, corresponding to FLOR1 (see arrow).

(C) Leaf interactors of the 11420 recombinant protein. In (1) and (2) two main protein bands are seen, corresponding to molecular masses of 37 and 32. In (3) Three proteins are detected with molecular masses of approximately 45, 32 and 14 . The $32 \mathrm{kDa}$ and $14 \mathrm{kDa}$ bands were identified as the catalytic domain of a PME (see arrows).

(D) Leaf interactors of the 11420-truncated protein. The $14 \mathrm{kDa}$ band shown in (3) (arrow) was identified as the same PME as in (C). 
A
1 MRLFVHLSIF FSILFITLPS SYSCTENDKN ALLQIKKALG NPPLLSSWNP RTDCCTGWTG
61 VECTNRRVTG LSVTSGEVSG QISYQIGDLV DLRTLDFSYL PHLTGNIPRT ITKLKNLNTL
121 YLKHTSLSGP IPDYISELKS LTFLDLSFNQ FTGPIPGSLS QMPKLEAIQI NDNKLTGSIP
181 NSFGSFVGNV PNLYLSNNKL SGKIPESLSK YDFNAVDLSG NGFEGDAFMF FGRNKTTVRV
241 DLSRNMFNFD LVKVKFARSI VSLDLSQNHI YGKIPPALTK LHLEHFNVSD NHLCGKIPSG

B
1 MKILSLSLLL LLAATVSHVQ SSASVPGLIE LLESNTIFGN EAELLEKEGL SINYPNCRSW
61 HLGVETSNII NFDTVPANCK AYVEDYLITS KQYQYDSKTV NKEAYFYAKG LALKNDTVNV
121 WIFDLDDTLL SSIPYYAKYG YGTENTAPGA YWSWLESGES TPGLPETLHL YENLLELGIE
181 PIIISDRWKK LSEVTVENLK AVGVTKWKHL ILKPNGSKLT QVVYKSKVRN SLVKKGYNIV
241 GNIGDQWADL VEDTPGRVFK LPNPLYYVPS

c
1 MAPSMREIFS KDNFKKNKKL VLLSAAVALL FVAAVAGISA GASKANEKRT LSPSSHAVLR
61 SSCSSTRYPE LCISAVVTAG GVELTSQKDV IEASVNLTIT AVEHNYFTVK KLIKKRKGLT
121 PREKTALHDC LETIDETLDE LHETVEDLHL YPTKKTLREH AGDLKTLISS AITNQETCLD
181 GFSHDDADKQ VRKALLKGQI HVEHMCSNAL AMIKNMTDTD IANFEQRAKI TSNNRRLKEE
241 NQETTVAVDI AGAGELDSEG WPTWLSAGDR RLLQGSGVKA DATVAADGSG TFKTVAAAVA
301 AAPENSNKRY VIHIKAGVYR ENVEVAKKKK NIMFMGDGRT RTIITGSRNV VDGSTTFHSA
361 TVAAVGERFL ARDITFONTA GPSKHOAVAL RVGSDFSAFY NCDMLAYODT LYVHSNROFF
421 VKCLIAGTVD FIFGNAAVVL ODCDIHARRP NSGOKNMVTA QGRTDPNONT GIVIORCRIG
481 ATSDLOSVKG SFPTYLGRPW KEYSOTVIMO SAISDVIRPE GWSEWTGTFA LNTLTYREYS
541 NTGAGAGTAN RVKWRGFKVI TAAAEAOKYT AGQFIGGGGW LSSTGFPFSL GL

Fig. 8. Sequences of protein bands identified by LC-MS/MS from the pull down essays using DUF642 proteins. Bands were excised from the gels and sent to the Proteomics Platform of the Eastern Genomics Center, Quebec, Canada for their identification. One protein with high hit was identified for each band sent. Peptides identified are shaded. (A) FLR1 (Q9LH52, At3g12145) amino acid sequence showing all the peptides identified in different protein fractions.

(B) VSP1 (Q93VJ6, At5g24780) amino acid sequence showing all the peptides identified in different protein fractions.

(C) PME (Q9LUL7 At3g14310) amino acid sequence showing all the peptides identified in different protein fractions. Underlines show signal peptide $\left({ }_{-} \_\right.$), inhibitory domain (_ and catalytic region $\left(\_\right.$). Note that all the peptides identified for this protein match the catalytic domain.

Subcellular localisation is also an important criterion for putative in vivo protein interactions. Three bands of 37, 32 and $14 \mathrm{kDa}$ were identified as fragments of the catalytic domain sequence from AtPME3 in leaf protein extracts. This electrophoretic pattern has been previously described in a purified citrus PME fraction. The enzymatic activity of the citrus PME fraction was not affected (Savary et al., 2002). However, this modification could be related to the subcellular localisation of AtPME3. The carboxylic $14 \mathrm{kDa}$ fragment, which interacts with the At5g11420-encoded protein, was previously detected in the apoplastic fluid of rosette leaves (Boudart el al., 2005), whereas the complete AtPME3 catalytic domain that specifically interacts with 32460 protein was identified in the cell wall proteomes of different plant tissues (Feiz et al., 2006). FLOR1 was also detected in cell wall proteomes from different tissues. 
The in vitro interactions of AtPME3 with the tested DUF642 proteins appear to be specific because no other PME was isolated with the affinity column. In particular, AtPME2 (At1g53830) shares a 90\% sequence similarity to AtPME3, which is also present in the leaves. This result and the high similarity of the primary and secondary structures of both DUF642 proteins suggest that DUF642 proteins can interact with the same protein but with different isoforms that result from posttranslational modifications (Figures 6 and 7). A specific protein interaction of AtPME3 has been previously described. The cellulose-binding protein (CBP) secreted by the nematode Heterodera schachtii and that is involved in the infection process specifically interacts with AtPME3, and no interaction was detected with AtPME2 (Hewezi et al., 2008).

The interaction of PMEs with proteins is highly involved in cell wall remodelling. The interaction of PME with proteins that inhibit its activity contributes to the modulation of the methylesterified state of the pectin in the cell wall during different developmental processes (Pelloux et al., 2007). An important role of pectin modifications in the regulation of cell wall mechanics in the apical meristem tissue has been suggested (Peaucelle et al., 2011). In root tips, highly esterified pectins were found in the proliferating zone, and non-esterified pectins were abundant in the cell walls of differentiating cells (Barany et al., 2010). During pollen germination, the pollen tube wall presents highly methylesterified pectins in the tip region and weakly methylesterified pectins along the tube (Dardelle et al., 2010). It has been suggested that a local relaxation of the transmitting tract cell wall resulting from changes in the methylesterification of pectins could facilitate the growth of the pollen tubes in the extracellular matrix of this female tissue (Lehner et al., 2010).

\section{Conclusions}

The DUF642 domain contains a carbohydrate-binding module (CBM) that could be involved in cell wall polysaccharides. The presence of these modules has been described in enzymes from bacteria that hydrolyse hemicelluloses and pectins to degrade the plant cell wall (Kellet et al., 1990; Mc Kie et al., 2001). The function of these modules appears to be related to a precise targeting to polymers in specific regions of plant cell walls during developmental processes. Plant cell wall proteins can act as bridging proteins that target specific cell wall regions and crosslink different networks (Hervé et al., 2010). Additionally, 32460 and 11420 proteins interact in vitro with a PME and a LRR protein that are closely related to PGIPs. These two DUF642 proteins could be scaffold proteins that promote the complexation of PME and LRR proteins to prevent the targeting of non-esterified pectins by pectin-degrading enzymes such as polygalacturonases.

Our results suggest that FLOR1 and AtPME3 interact with the 11420 and 32460 DUF642 proteins, but the precise biochemical and biological functions remain to be determined.

\section{Acknowledgments}

This work was supported by PAPIIT grant IN220980 (Universidad Nacional Autónoma de México). EZS is a PhD student (Posgrado en Ciencias Biomédicas, UNAM) and received a CONACyT fellowship. 


\section{References}

Abrahams, S., Hayes, C.M., \& Watson, J. M. (1995). Expression pattern of three genes in the stem of Lucerne (Medicago sativa). Plant Molecular Biology, Vol. 27, No. 3, (February), pp 513-528, ISSN 0167-4412.

Acevedo, G.F., Gamboa, A., Páez-Valencia, J., Izaguirre-Sierra, M., \& Alvarez-Buylla, R.E. (2004). FLOR1, a putative interaction partner of the floral homeotic protein AGAMOUS, is a plant-specific intracellular LRR. Plant Science, Vol.167, No. 2, (August), pp. 225-231, ISSN 0168-9452.

Albert, V.A., Soltis, D. E., Carlson, J.E., Farmerie, W.G., Kerr Wall, P., Ilut, D.C., Solow, T.M., Mueller, L.A., Landherr, L.L., Hu, Y.I., Buzgo, M., Kim, S., Yoo, M.J., Frohlich, M.W., Perl-Treves, R., Schlarbaum, S,E., Bliss, B.J., Zhang, X., Tanksley, S.D., Oppenheimer, D.G., Soltis, P.S., Ma, H., de Pamphilis, C.W., \& Leebans-Mack, J.H. (2005). Floral gene resources from basal angiosperms for comparative genomics research. BMC Plant Biology, Vol. 5, No 5, (March), pp, ISSN 1471-2229.

Barcalá, M., García, A., Cabrera, J., Casson, S., Lindsey, K., Favery, B., García-Casado, G., Solano, R., Fenoll, C., \& Escobar, C. (2010). Early transcriptomic events in microdissected Arabidopsis nematode-induced giant cells. Plant Journal, Vol. 61, No. 4, (February), pp. 698-712, ISSN 0960-7412.

Barany, I., Fadón, B., Risueño, M.C., \& Testillano, P.S. (2010). Cell wall components and pectin esterification levels as markers of proliferation and differentiation events during pollen development and embryogenesis in Capsicum annuum L. Journal of Experimental Botany, Vol. 61, No. 4, (February), pp. 1159-1175, ISSN 0022-0957.

Baumberger, N., Doesseger, B., Guyot, R., Diet, A., Parsons, R.L., Clark, M.A., Simmons, M.P., Bedinger, P., Goff, S.A., Ringli, C., \& Keller, B. (2003). Whole-genome comparison of leucine-rich repeat extensins in Arabidopsis and rice. A conserved family of cell wall proteins from vegetative and a reproductive clade. Plant Physiology, Vol. 131, No. 3, (March), pp. 1313-1326, ISSN 0032-0889.

Bayer, E.M., Bottrill, A.R., Walshaw, J., Vigouroux, M., Naldrett, M.J., Thomas, C.L., \& Maule, A. (2006). Arabidopsis cell wall proteome defined using multidimensional protein identification technology. Proteomics, Vol. 6, No. 1, (January), pp. 301-311, ISSN 1615-9853.

Becnel, J., Natarajan, M., Kipp, A., \& Braam, J. (2006). Developmental expression patterns of Arabidopsis XTH reported by transgenes and Genevestigator. Plant Molecular Biology, Vol. 61, No. 3, (June), pp. 451-467, ISSN 0167-4412.

Bischoff, V., Nita, S., Neumetzler, L., Schindelasch, D., Unrbain ,A., Eshed, R., Persson, S., Delmer, D., \& Scheible, W.R. (2010a). TRICHOME BIREFRINGENCE and its homolog At5g01360 encode plant-specific DUF231 proteins required for cellulose biosynthesis in Arabidopsis. Plant Physiology, Vol. 153, No. 2, (June), pp. 590-602, ISSN 0032-0889.

Bischoff, V., Selbig, J., \& Scheible, W.R. (2010b). Involvement of TBL/DUF231 proteins into cell wall biology. Plant Signaling \& Behavior, Vol. 5, No. 8, (August), pp. 1057-1059, ISSN 1559-2316.

Borderies, G., Jamet, E., Lafitte, C., Rossignol, M., Jauneau, A., Boudart, G., Monsarrat, B., Esquerré-Tugayé, M.T., Boudet, A., \& Pont-Lezica, R. (2003). Proteomics of loosely bound cell wall proteins of Arabidopsis thaliana cell suspension cultures: a critical 
analysis. Electrophoresis, Vol. 24, No. 19-20, (October), pp. 3421-3432, ISSN 01730835 .

Borner, G.H., Lilley, K.S., Stevens, T.J., \& Dupree, P. (2003). Identification of glycosilphosphatidylinositol anchored proteins in Arabidopsis. A proteomic and genomic analysis. Plant Physiology, Vol. 132, No. 2, (June), pp. 568-577, ISSN 00320889 .

Boudart, G., Jamet, E., Rossignol, M., Lafitte, C., Borderies, G., Jauneau, A., EsquerréTugayé, M.T., \& Pont-Lezica, R. (2005). Cell wall proteins in apoplastic fluids of Arabidopsis thaliana rosettes: Identification by mass spectometrometry and bioinformatics. Proteomics, Vol. 5, No.1 , (January), pp. 212-221, ISSN 1615-9853.

Cassab, G.I. (1998). Plant cell wall proteins. Annual Reviews of Plant Physiology and Plant Molecular Biology, Vol. 49, pp. 281-309, ISSN 1040-2519.

Charmont, S., Jamet, E., Pont-Lezica, R., \& Canut, H. (2005). Proteomic analysis of secreted proteins from Arabidopsis thaliana seedlings: improved recovery following removal of phenolic compounds. Phytochemistry, Vol. 66, No. 4, (February), pp. 453-461, ISSN 0031-9422.

Chibani, K., Ali-Rachedi, S., Job, C., Job, D., Jullien, M., \& Grappin, P. (2006). Proteomic analysis of seed dormancy in Arabidopsis. Plant Physiology, Vol.142, No. 4, (December), pp. 1493-1510, ISSN 0032-0889.

Chivasa, S., Ndimba, B.K., Simon, W.J., Robertson, D., Yu, X.L., Knox, J.P., Bolwell, P., \& Slabas, A.R. (2002). Proteomic analysis of Arabidopsis thaliana cell wall. Electrophoresis, Vol. 23, No. 11, (Junio), pp. 1754-1765, ISSN 0173-0835.

Clark, S.E., Williams, R.W., \& Meyerowitz, E.M. (1997). The CLAVATA1 gene encodes a putative receptor kinase that controls shoot and meristem size in Arabidopsis. Cell, Vol. 89, No. 4, (May), pp. 575-585, ISSN 0092-8674.

Dardelle, F., Lehner, A., Ramdani, Y., Basrdor, M., Lerouge, P., Driouich, A., \& Mollet, J.C. (2010). Biochemical and immunocytological characterizations of Arabidopsis pollen tube cell wall. Plant Physiology, Vol. 153, No. 4, (August), pp. 1563-1576, ISSN 00320889 .

Depuydt, S., Trenkamp, S., Fernie, A.R., Elftieh, S., Renou, J.P., Vuylsteke, M., Holsters, M., \& Vereecke, D. (2009) An integrated genomics approach to define niche establishment by Rhodococcus fascians. Plant Physiology, Vol. 149, No. 3, (March), pp. 1366-1386, ISSN 0032-0889.

Dhonukshe, P., Baluska, F., Schlicht, M., Hlavacka, A., Samaj, J., Friml, J., \& Gadella, T.W.J (2006). Endocytosis of cell surface material mediates cell plate formation during plant cytokinesis. Developmental Cell, Vol. 10, No. 1 (January), pp. 137-150, ISSN 1534-5807.

Di, C., Zhang, M., Xu, S., Cheng, T., \& An, L. (2006). Role of poly-galacturonase inhibiting protein in plant defense. Critical Reviews of Microbiology, Vol. 32, No. 2, (January), pp 91-100, ISSN 1040-841X.

Dunkley, T.P., Hester, S., Shadforth, I.P., Runions, J., Weimar, T., Hamton, S.L., Griffin, J.L., Bessant, C., Brandizzi, F., Hawes, C., Watson, R.B., Dupree, P., \& Lilley, K.S. (2006). Mapping the Arabidopsis organelle proteome. Proceedings of the National Academy of Science, Vol. 103, No. 11, (April), pp. 1128-1134, ISSN 1091-6490.

Ehlting, J., Chowrira, S.G., Matthews, N., Eschliman, D.S., Arimura, G., \& Bohlmann, J. (2008). Comparative transcriptome analysis of Arabidopsis thaliana infested by 
diamond back moth (Plutella xylostella) larvae reveals signatures of stress response, secondary metabolism, and signalling. BMC Genetics, Vol. 9, No. 9 (April), pp. 154160, ISSN 1471-2156.

Feiz, L., Irshad, M., Pont-Lezica, R.F., Canut, H., \& Jamet, E. (2006). Evaluation of cell wall preparations for proteomics: A new procedure for purifying cell walls from Arabidopsis hypocotyls. Plant Methods, Vol. 2, No. 10, (May), pp. 13, ISSN 17464811.

Feraru, E., Feraru, M.I., Kleine-Vehm, J., Martiniere, A., Mouille, J., Vanneste, S., Vernhettes, S., Runions, J., \& Friml, J. (2011). PIN polarity maintenance by the cell wall in Arabidopsis. Current Biology, Vol. 21, No. 4, (February), pp. 338-343, ISSN 09609822.

Gaboriaud, C., Bissery, V., Benchetrit, T., \& Mornon, J.P. (1987) Hydrophobic cluster analysis: an efficient new way to compare and analyse amino acid sequences. FEBS Letters, Vol. 224, No. 1, (November), pp. 149-155, ISSN 0014-5793.

Gamboa, A., Páez-Valencia, J., Acevedo, G.F., Vázquez-Moreno, L., \& Alvarez-Buylla, R.E. (2001). Floral transcription factor AGAMOUS interacts in vitro with a leucine-rich repeat and an acid phosphatase complex. Biochemical and Biophysics Research Communications, Vol. 288, No. 4, (November), pp. 1018-1026, ISSN 0006-291X.

Goda, H., Sawa, S., Asami, T., Fujioka, S., Shimada, Y., \& Yoshida, S. (2004). Comprehensive comparison of auxin-regulated and brassinosteroid regulated genes in Arabidopsis. Plant Physiology, Vol. 134, No. 4, (April), pp. 1555-1573, ISSN 0032-0889.

González-Carranza, Z.H., Elliot, K.A., \& Roberts, J.A. (2007). Expression of polygalacturonases and evidence to support its role Turing cell separation processes in Arabidopsis thaliana. Journal of Experimental Botany, Vol 58, No. 13, (October), pp. 3719-3730, ISSN 0032-0889.

Grunewald, W., van Noorden, G., Van Isterdaal, G., Beeckman, T., Gheysen, G., \& Mathesius, U. (2009). A manipulation of auxin transport in plant roots during Rhizobium simbiosis and nematode parasitism. Plant Cell Vol. 21, No. 9, (September), pp. 2553-2562, ISSN 1040-4651.

Guenin, S., Mareck, A., Rayon, C., Lamour, R., Assoumou, Ndong, Y., Domon, J.M., Senechal, F., Fourner, F., Jamet, E., Canut, H., Percoco, G., Moville, G., Rolland, A., Rusterucci, C., Guerineau, F., Van Wuytswinkel, O., Gillet, F., Driovich, A., Lerouge, P., Gutierrez, L, \& Pelloux, J. (2011). Identification of pectin methylesterase 3 as a basic pectin methylesterase isoform involved in adventitious rooting in Arabidopsis thaliana. New Phytologist, Vol. 192, No. 1, (October), pp. 114126, ISSN 0028-646X.

Harpster, M.H., Brummell, D.A., \& Dunsmuir, P. (2002). Suppression of a ripening-related endo-1,4- $\beta$-glucanase in transgenic pepper fruit does not prevent depolymerisation of cell wall polysaccharides during ripening. Plant Molecular Biology, Vol. 50, No. 3, (October), pp. 345-355, ISSN 0167-4412.

Havlis, J., Thomas, H., Sebela, M., \& Shevchenko, A. (2003). Fast-response proteomics by accelerated in-gel digestion of proteins. Analytical Chemistry, Vol. 75, No. 6, (March), pp. 1300-1306, ISSN 0003-2700.

Held, M.A., Be, E., Zemelis, S., Withers, S., Wilkerson, C., \& Brandizzi, F. (2011). CRG3: A golgi-localized protein influencing homogalacturonan methylesterification. Molecular Plant, Vol. 4, No. 5, (September), pp. 832-844, ISSN 1674-2052. 
Hervé, C., Rogowski, A., Blake, A.W., Marcus, S.E., Gilbert, H.J., \& Knox, J.P. (2010). Carbohydrate-binding modules promote the enzymatic deconstruction of intact plant cell walls by targeting and proximity effects. Proceedings of the National Academy of Science, Vol. 107, No. 34, (August), pp 15293-15298, ISSN 1091-6490.

Hewezi, T., Howe, P., Maier, T,R., Hussey, R.S., Mitchum, M.G., Davis, E.L., \& Baum, T.J. (2009). Cellulose binding protein from the parsitic nematode Heterodera schachtii interacts with Arabidopsis pectin methyl-esterase: cooperative cell-wall modification during parasitism. Plant Cell, Vol. 20, No. 11, (November), pp. 30803093. ISSN 1040-4651.

Hoffman, R.M., and Turner, J.G. (1984), Occurrence and specificity of an endopolygalacturonase inhibitor in Pisum sativum. Physiol. Plant Pathol. Vol. 24, No. 1, (January), pp. 49-59, ISSN 0048-4059.

Hu, J., Barlet, X., Deslandes, L., Hirsch, J., Feng, X., Somssich, I., \& Marco, Y. (2008). Transcriptional responses of Arabidopsis thaliana during wilt disease caused by soilborne phytopathogenic bacterium Ralstonia solanacearum. PLoS ONE, Vol. 3, No. 7, (July), e2589, ISSN 1932-6203.

Irshad, M., Canut, H., Borderies, G., Pont-Lezica, R., \& Jamet, E. (2008). A new picture of cell wall protein dynamics in elongating cells of Arabidopsis thaliana; confirmed actors and new comers. BMC Plant Biology, Vol. 8, (September), pp. 94-103.

Jamet, E., Canut, H., Boudart, G., \& Pont-Lezica, R.F. (2006). Cell wall proteins: a new insight through proteomics. Trends in Plant Sciences, Vol. 11, No. 1, (January), pp. 33-39. ISSN 1360-1385.

Juge, N (2006). Plant proteins inhibitors of cell wall degrading enzymes. Trends in Plant Sciences. Vol. 11, No. 7, (July), pp. 359-367. ISSN 1360-1385.

Kajava, A.V. (1998). Structural diversity of Leucine-rich repeat proteins. Journal of Molecular Biology, Vol. 277, No. 3, (April), pp. 519-527, ISSN 0022-2836.

Keller, A., Nesvizhskii, A.I., Kolker, E., \& Aebersold, R. (2002). Empirical statistical model to estimate the accuracy of peptide identifications made by MS/MS and database search. Analytical Chemistry, Vol. 74, No. 20, (October), pp. 5383-5392, ISSN 00032700.

Kellet, L.E., Poole, D.M., Ferreira, L.M., Durrant, A.J., Hazlewood, G.P., \& Gilbert, H.J. (1990). Xylanase B and arabinofuranosidase from Pseudomonas fluorescens subsp. cellulosa contain identical cellulose-binding domains and are encoded by adjacent genes. Biochemical Journal, Vol. 272, No. 2, (December), pp. 369-376. ISSN 0244-6021.

Kreps, J.A., Wu, Y., Chang, H-S., Zhu, T., Wang, X., \& Harper, J.F. (2002). Transcriptome changes for Arabidopsis in response to salt, osmotic, and cold stress. Plant Physiology, Vol. 130, No. 4, (December), pp. 2129-2141, ISSN 0032-0889.

Lannoo, N., Vanderborre, G., Miersch, O., Smagghe, G., Wasternack, C., Peumans, W.J., \& Van Damme, E.J. (2007). The jasmonate-induced exporession of the Nicotiana tabacum in leaf lectins. Plant and Cell Physiology, Vol. 48, No. 8, (August), pp. 12071218, ISSN 0032-0781.

Lee, C.W., Efetova, M., Engelmann, J.C., Kramell, R., Wastermack, C., Ludwig-Müller, J., Hedrich, R., \& Deeken, R. (2009). Agrobacterium tumefaciens promotes tumor induction by modulating pathogen defense in Arabidopsis thaliana. Plant Cell, Vol. 21, No. 9, (September), pp. 2948-2962, ISSN 1040-4651. 
Lehner, A., Dardelle, F., Soret-Morvan, O., Lerouge, P., Driouich, A., \& Mollet, J.C. (2010). Pectins in the cell wall of Arabidopsis thaliana pollen tube and pistil. Plant Signaling $\mathcal{E}$ Behavior, Vol. 5, No. 10, (October), pp. 1282-1285.

Mc Kie, V.A., Vincken, J.O., Voragen, A.G., van der Broek, L.A., Stimson, E., \& Gilbert H.J. (2001). A new family of rhamnogalacturonan lyases contains an enzyme that binds to cellulose. Biochemical Journal, Vol. 355, No. 1, (April), pp. 167-177. ISSN 02446021.

Membré, N., Bernier, F., Staiger, D., \& Berna, A. (2000). Arabidopsis thaliana germin-like proteins: common and specific features point to a variety of functions. Planta, Vol. 211, No. 3, (August), pp.345-354, ISSN 0032-0935.

Micheli, F. (2001). Pectin methylesterases : cell wall enzymes with important roles in plant physiology. Trends in Plant Science, Vol. 6, No. 9, (September), pp. 414-418. ISSN 1360-1385.

Minic, Z., Jamet, E., Négroni, L., der Garabedian, A., Zivy, M., \& Jouanin, L. (2007). A subproteome of Arabidopsis thaliana mature stems trapped on Concanavalin A is enriched in cell wall glycoside hydrolases. Journal of Experimental Botany, Vol. 58, No. 10, (May), pp. 2503-2512, ISSN 0022-0957.

Passardi, F., Penel, C., \& Dunand, C. (2004). Performing the paradoxical: how plant peroxidises modify the cell wall. Trends in Plant Science, Vol. 9, No. 11, (November), pp. 534-540, ISSN 1360-1385.

Passardi, F., Tognolli, M., De Meyer, M., Penel, C., Dunand C., (2006). Two cell wall associated peroxidases from Arabidopsis influence root elongation. Planta, Vol. 223, No. 5, (April), pp. 965-974, ISSN 0032-0935.

Peaucelle, A., Braybrook, S.A., Le Guillou, L., Bron, E., Kuhlemeier, C., \& Höfte, H. (2011). Pectin induced changes in cell wall mechanics underlie organ initiation in Arabidopsis. Current Biology, Vol. 21, No. 20, (October), 1720-1726, ISSN 0960-9822.

Pelloux, J., Rustérucci, C., \& Mellerowicz, E.J. (2007). New insights into pectin methylesterase structure and function. Trends in Plant Science, Vol. 12, No. 6, (June), pp. 267-277, ISSN 1360-1385.

Reinhardt, D., Wittwer, F., Mandel, T., \& Kuhlemeier, C. (1998). Localized upregulation of a new expansin gene predict the site of leaf formation in the tomato meristem. Plant Cell, Vol. 10, No. 9, (September), pp. 1427-143,. ISSN 1040-4651.

Röckel, N., Wolf, S., Kost, B., Rausch, T., \& Greiner, S. (2008). Elaborate spatial patterning of cell wall PME and PMEI at the pollen tube tip involves PMEI endocytosis and reflects the distribution of esterified and de-esterified pectin. Plant Journal, Vol. 53, No. 1, (January), pp. 133-143, ISSN 0960-7412.

Ruppert, M., Woll, J., Giritch, A., Genady, E., Ma, X., \& Stockigt, J. (2005). Functional expression of an ajmaline pathway-specific esterase from Rauvolfia in a plant-virus expression system. Planta, Vol. 222, No. 5, (November), pp. 888-898, ISSN 00320935.

Sampedro, J., \& Cosgrave, D.J. (2005). The expansin superfamily. Genome Biology, Vol. 6, No. 12, (November), pp.242-250, ISSN 1474-7596.

Savary, B.J., Hotchkiss, A.T., \& Cameron, R.G. (2002). Characterization of a salt independent pectin methylesterase purified from Valencia orange peel. Journal of Agriculture and Food Chemistry, Vol. 50, No. 12, (June), pp. 3553-3558, ISSN 0021-8561. 
Shevchenko, M., Wilm, O., Vorm, O., \& Mann, M. (1996). Mass spectrometric sequencing of proteins from silver-stained polyacrylamide gels. Analytical Chemistry, Vol. 68, No. 5 (March), pp. 850-858, ISSN 0003-2700.

Sterling, J.D., Quigley, H.F., Oerallana, A., \& Mohnen, D. (2001). The catalytic site of the pectin biosynthetic enzyme alpha-1,4-galacturonosyltransferases is located in the lumen of the Golgi. Plant Physiology, Vol. 127, No. 1, (September), pp. 360-371, ISSN 0032-0889.

Thomas, C.L., Bayer, E.M., Ritzenthaler, C., Fernandez-Calvino, L., \& Maule, A.J. (2008). Specific targeting of a plasmodesmal protein affecting cell-to-cell communication. PLoS Biology, Vol. 6, No.1, (January), e7, ISSN 1932-6203.

Tung, C.W., Dwyer, K.G., Nasrallah, M.E., \& Nasrallah, J.B. (2005). Genome-wide identification of genes expressed in Arabidopsis pistils specifically along the path of pollen tube growth. Plant Physiology, Vol. 138, No. 2, (June), pp. 977-998, ISSN 0032-0889.

Van Damme, E.J., Lanoo, N., Fouquaert, E., \& Peumans, W.J. (2004). The identification of inducible cytoplasmic/nuclear carbohydrate-binding proteins urges to develop novel concept about the role of plant lectins. Glycoconjugate Journal, Vol. 20, No. 7-8, pp. 449-460. ISSN 0282-0080.

van der Hoorn, R.A.L. (2008). Plant proteases: from phenotypes to molecular mechanisms. Annual Review of Plant Biology, Vol. 59, No. 191, (June), pp. 191-223, ISSN 1543-5008.

Wellmer, F., Riechemann, J.L., Alves-Ferreira, M., \& Meyerowitz, E.M. (2004). Genome wide analysis of spatial gene expression in Arabidopsis flowers. Plant Cell, Vol. 16, No. 5 (May), pp. 1314- 1326, ISSN 1040-4651.

Wolf, S., Mouille, G., \& Pelloux, J. (2009). Homogalacturonan methyl-esterification and plant development. Molecular Plant Vol. 5, No. 2 (September), pp. 851-860, ISSN 16742052.

Wraczeck, M., Brosché, M., Salojärvi, J., Kangasjärvi, S., Idänheimo, N., Mersmann, S., Robatzek, S., Karpinski, S., Karspinska, B., \& Kangasjärvi, J. (2010). Transcriptional regulation of CRK/DUF26 group of receptor-like protein kinases by ozone and plant hormones in Arabidopsis. BMC Plant Biology, Vol. 10, No. 95, (May), pp 95101, ISSN 1471-2229-

Wu, H.C., Hsu, S.F., Luo, D.L., Chen, S.J., Huang, W.D., Lur, H.S., \& Jinn, T.L. (2010). Recovery of heat shock-triggered released apoplastic Ca2+ accompanied by pectin methylesterase activity is required for thermotolerance in soybean seedlings. Journal of Experimental Botany, Vol. 61, No. 10, (June), pp. 2843-2852, ISSN 0022-0957. 


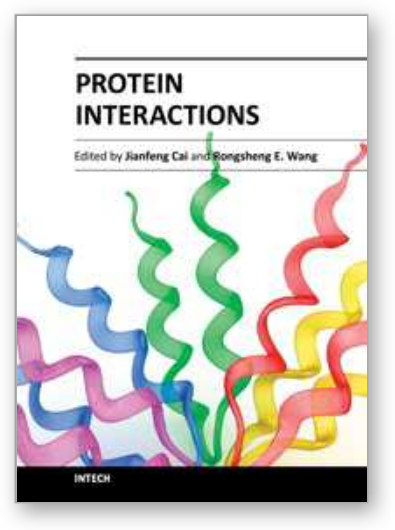

\author{
Protein Interactions \\ Edited by Dr. Jianfeng Cai
}

ISBN 978-953-51-0244-1

Hard cover, 464 pages

Publisher InTech

Published online 16, March, 2012

Published in print edition March, 2012

Protein interactions, which include interactions between proteins and other biomolecules, are essential to all aspects of biological processes, such as cell growth, differentiation, and apoptosis. Therefore, investigation and modulation of protein interactions are of significance as it not only reveals the mechanism governing cellular activity, but also leads to potential agents for the treatment of various diseases. The objective of this book is to highlight some of the latest approaches in the study of protein interactions, including modulation of protein interactions, development of analytical techniques, etc. Collectively they demonstrate the importance and the possibility for the further investigation and modulation of protein interactions as technology is evolving.

\title{
How to reference
}

In order to correctly reference this scholarly work, feel free to copy and paste the following:

Esther Zúñiga-Sánchez and Alicia Gamboa-de Buen (2012). The Two DUF642 At5g11420 and At4g32460Encoded Proteins Interact In Vitro with the AtPME3 Catalytic Domain, Protein Interactions, Dr. Jianfeng Cai (Ed.), ISBN: 978-953-51-0244-1, InTech, Available from: http://www.intechopen.com/books/proteininteractions/the-two-duf642-at5g11420-and-at4g32460-encoded-proteins-interact-in-vitro-with-the-atpme3catalytic

\section{INTECH}

open science | open minds

\section{InTech Europe}

University Campus STeP Ri

Slavka Krautzeka 83/A

51000 Rijeka, Croatia

Phone: +385 (51) 770447

Fax: +385 (51) 686166

www.intechopen.com

\section{InTech China}

Unit 405, Office Block, Hotel Equatorial Shanghai

No.65, Yan An Road (West), Shanghai, 200040, China

中国上海市延安西路65号上海国际贵都大饭店办公楼 405 单元

Phone: +86-21-62489820

Fax: $+86-21-62489821$ 
(C) 2012 The Author(s). Licensee IntechOpen. This is an open access article distributed under the terms of the Creative Commons Attribution 3.0 License, which permits unrestricted use, distribution, and reproduction in any medium, provided the original work is properly cited. 